\title{
Surface subsidence and uplift above a headrace tunnel in metamorphic basement rocks of the Swiss Alps as detected by satellite SAR interferometry
}

\author{
Tazio Strozzi ${ }^{\mathrm{a}, *}$, Reynald Delaloye ${ }^{\mathrm{b}}$, Damien Poffet ${ }^{\mathrm{b}}$, Jürgen Hansmann ${ }^{\mathrm{c}}$, Simon Loew ${ }^{\mathrm{c}}$ \\ a Gamma Remote Sensing, Worbstrasse 225, 3073 Gümligen, Switzerland \\ ${ }^{\mathrm{b}}$ Department of Geosciences, Geography Unit, University of Fribourg, Ch. du Musée 4, 1700 Fribourg, Switzerland \\ ' Engineering Geology, Department of Earth Sciences, ETH Zürich, Sonneggstrasse 5, 8092 Zürich, Switzerland
}

\begin{abstract}
Surface subsidence associated with the construction of a headrace tunnel in the Swiss Alps at more than $2000 \mathrm{~m}$ above sea level (a.s.l.) has been detected at two locations with satellite differential Synthetic Aperture Radar (SAR) interferometry. At the first location, a subsidence trough of about $4 \mathrm{~cm}$ in the satellite line-ofsight direction following the headrace tunnel axes has been measured between August 1995 and August 1996. Similar values from SAR data of ascending and descending orbits indicate displacements in the vertical direction of the movement. In the second case, a symmetric cone of depression with a maximum displacement of about $4 \mathrm{~cm}$ between 1995 and 1997 has been observed above the tunnel. Differences in the results from satellite SAR data of ascending and descending orbits indicate that the direction of displacement in this second case was not entirely vertical. Large-scale consolidation associated with pore-pressure reduction in the rock mass arising from tunnel drainage at about 200-400 m depth beneath the topographical surface is believed to be the contributing mechanism (Zangerl et al., 2008a, 2008b). Evidence for this process is based on pore pressure recordings in nearby deep wells. In both areas, the subsidence was followed by a small uplift of about one centimeter between 1997 and 1999, after the tunnel was cased with permeable concrete segments. This partial recovery is also visible in pore pressure records and can be related to the elastic components of rock mass deformation.
\end{abstract}

\section{Introduction}

Surface subsidence related to fluid extraction, mining, or tunnel drainage is commonly experienced in loosely consolidated sediments or high porosity rocks (Schmidt, 1989; Spreckels et al., 2001). However, the development of surface settlements above low-porosity, fractured rock is less recognized, even though large reductions in pore pressure can occur when driving a deep tunnel. Examples were reported in three cases in the Swiss Alps. At the Zeuzier arch dam in the western part of the country $13 \mathrm{~cm}$ of vertical settlement were associated with the driving of an investigation adit $1.5 \mathrm{~km}$ away through a confined, fractured, marly-limestone aquifer (Lombardi, 1988). Around 800 hundred meters above the Gotthard highway tunnel in central Switzerland $12 \mathrm{~cm}$ of subsidence was observed in fractured crystalline rock by high precision leveling along the Gotthard pass road 25 years after tunnel construction (Zangerl et al., 2008a, 2008b). Above the Gotthard Basetunnel a comprehensive geodectic monitoring system has recorded transient surface settlements of up to

\footnotetext{
* Corresponding author.

E-mail addresses: strozzi@gamma-rs.ch (T. Strozzi), reynald.delaloye@unifr.ch (R. Delaloye), damien.poffet@unifr.ch (D. Poffet), juergen.hansmann@erdw.ethz.ch (J. Hansmann), simon.loew@erdw.ethz.ch (S. Loew).
}

$4 \mathrm{~cm}$ within the first 4 years after tunnel excavation (Löw et al., 2007). Although these settlements may appear to be small compared to those associated with ground water or oil and gas withdrawal from more compliant porous media, they are large enough to adversely affect the structural integrity of sensitive concrete structures on the surface like thin arch dams.

Between 1993 and 1998 the so-called Cleuson-Dixence hydroelectric scheme was built to increase the production capacity of the Grande Dixence dam in the Swiss Alps (Cleuson-Dixence Construction, 2009). The scheme includes a headrace tunnel $15.8 \mathrm{~km}$ long from the dam to Tracouet (see Fig. 1), followed by an inclined steel lined shaft $4.3 \mathrm{~km}$ long down to the power plant on the main Rhone valley. The headrace tunnel has a diameter of 5.6 to $5.8 \mathrm{~m}$ and is passing mostly 100 to more than $400 \mathrm{~m}$ beneath the ground surface through various geological entities belonging to the Penninic nappes, which consist here mostly of metamorphic crystalline rocks (gneiss, schists and micaschists, in some cases highly fractured). Geological and hydrological investigations concerning the head-race tunnel were performed by Bureau Norbert (1998a, 1998b). The type of rocks, their level of fracturation as well as the water inflows in the tunnel were recorded during the construction works. Hydrogeological investigations were also performed before the tunnel construction and for the whole massive a permeability on the order of $10^{-7} \mathrm{~m} / \mathrm{s}$ was estimated, with locally large differences 


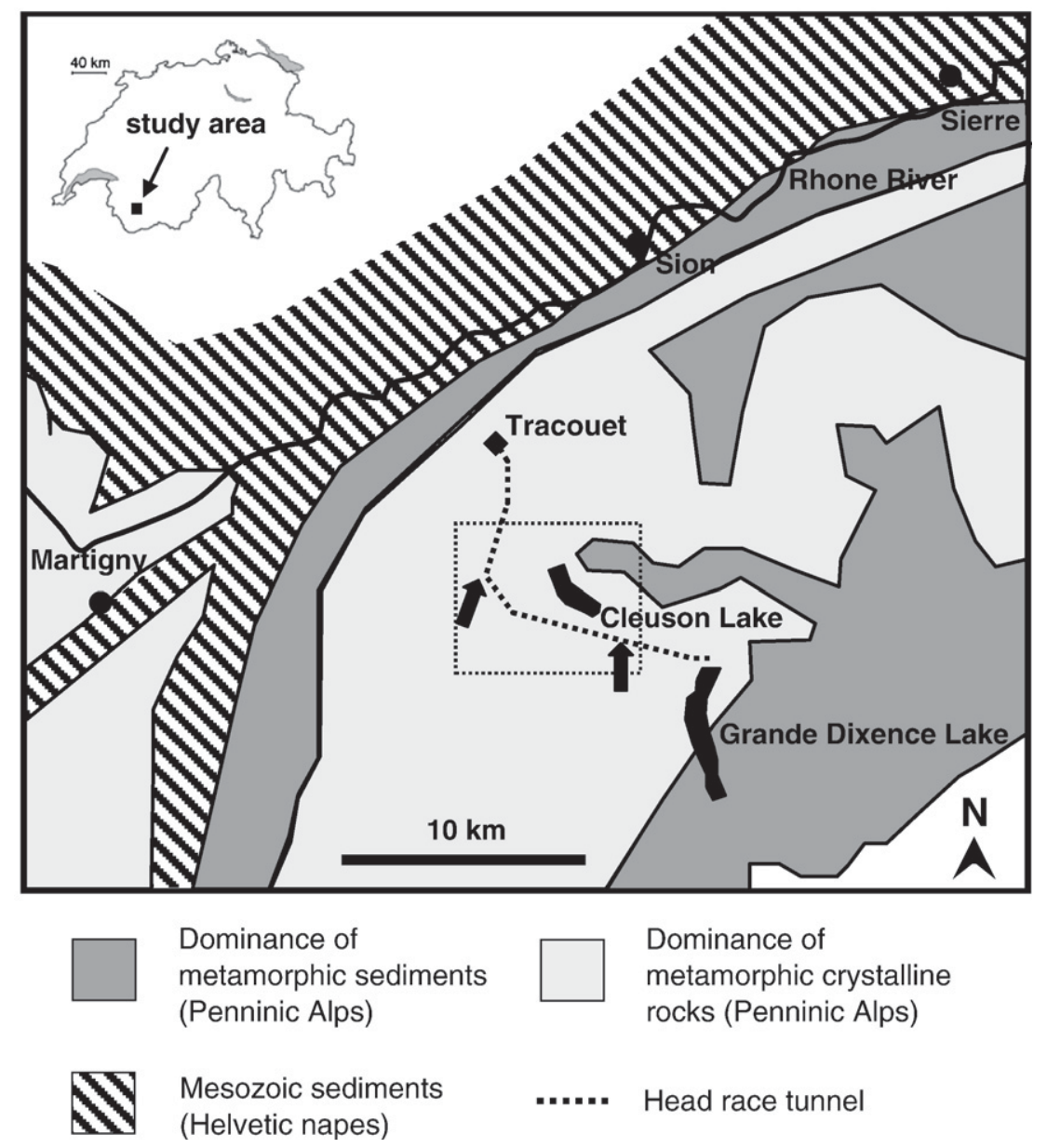

Fig. 1. Geographical and geological setting of the study region in the Swiss Alps showing the outline of the head race tunnel. The dashed box highlights the area shown in Fig. 2, the two arrows indicate where surface subsidence has been detected with DInSAR.

depending on the fracturation state. Whereas most of the gallery is drilled through the saturated zone, the extent of higher permeability sections with conductive and interconnected fracture systems is rather limited. Higher permeability sections (groundwater compartments) are partially confined by clay rich cataclastic tectonic faults (cataclasites, kakirites). In order to measure the piezometric level of various groundwater compartments along the headrace tunnel before and after construction about ten piezometric boreholes with pressure gauges were drilled at different locations.

The morphology of the area above the tunnel is typical of the periglacial (non-glaciated) high alpine zone. It consists of a succession of valleys and cirques eroded by glaciers during Pleistocene glaciations, separated by sharp crest lines. Late glacial moraines and relict rock glaciers are numerous in the valleys and cirques. Slopes are moderately to steeply inclined and currently subjected to erosion processes typical for the periglacial setting (frost weathering, rockfall activity, permafrost creep, etc.). A few large deep-seated landslide features can be recognized, some of them being active (Delaloye et al., 2005). There is almost no tree at altitudes of more than $2200 \mathrm{~m}$ a.s.l. and only small vegetation is present. We detected spatial and temporal patterns of surface displacement related to the construction of the Cleuson-Dixence headrace tunnel by satellite SAR interferometry. In the following, we describe data, methods and results of our investigations and discuss possible mechanisms for the observed subsidences and uplifts. Detailed numerical analyses of the surface deformations and pore pressure changes will be presented in a subsequent companion paper.

\section{Data and methods}

Satellite differential SAR interferometry (DInSAR) is an established technique for the mapping of geophysical surface displacements at cm to mm resolution (Bamler \& Hartl, 1998; Rosen et al., 2000; Strozzi et al., 2001). In mountainous terrain the major limiting factors of DInSAR are temporal decorrelation and the SAR image geometry, both leading to incomplete spatial coverage (Kääb et al., 2005; Kenyi \& Kaufmann, 2003; Rott et al., 1999; Strozzi et al., 2004). Over alpine areas, where dense vegetation is no longer present, high coherence is regularly observed during the snow free period between early summer and mid fall. The very rugged topography of alpine regions causes incomplete coverage due to layover and shadowing. In addition, the technique measures the component of the displacement along the satellite line-of-sight direction and is therefore better suited for detection and monitoring of movements in the vertical and eastwest directions.

In this study, a series of 11 SAR interferograms from the European Remote Sensing Satellites ERS-1 and ERS-2 and the Japanese Earth Resources Satellite JERS-1 with short baselines has been analyzed (Table 1). The interferograms were computed from SAR images acquired along the ascending and descending orbits for a better illumination of the area of interest. The topographic reference was determined from an external Digital Elevation Model (DEM) with a spatial resolution of $25 \mathrm{~m}$ and an estimated vertical accuracy of $3 \mathrm{~m}$ and subtracted from the interferograms. Phase unwrapping of the differential interferograms (Rosen et al., 1994) permitted the quantitative measurement of the displacement in the line-of-sight direction. 
Table 1

Acquisition time interval and perpendicular baseline of the SAR interferograms.

\begin{tabular}{lllccccl}
\hline Sensor & Date 1 & Date 2 & Interval & Baseline & Track & Frame & Orbit \\
\hline ERS & 1993.09 .05 & 1995.10 .03 & 758 days & $172 \mathrm{~m}$ & 029 & 920 & Ascending \\
ERS & 1995.08 .29 & 1995.08 .30 & 1 day & $86 \mathrm{~m}$ & 029 & 920 & Ascending \\
ERS & 1995.08 .30 & 1996.08 .14 & 350 days & $47 \mathrm{~m}$ & 029 & 920 & Ascending \\
ERS & 1995.10 .03 & 1997.10 .08 & 736 days & $85 \mathrm{~m}$ & 029 & 920 & Ascending \\
ERS & 1995.10 .03 & 1998.07 .14 & 1015 days & $35 \mathrm{~m}$ & 029 & 920 & Ascending \\
ERS & 1997.10 .08 & 1998.07 .14 & 279 days & $49 \mathrm{~m}$ & 029 & 920 & Ascending \\
ERS & 1998.09 .22 & 2000.07 .19 & 666 days & $62 \mathrm{~m}$ & 029 & 920 & Ascending \\
ERS & 1997.09 .03 & 1999.06 .29 & 736 days & $35 \mathrm{~m}$ & 029 & 920 & Ascending \\
ERS & 1995.08 .29 & 1996.08 .14 & 350 days & $20 \mathrm{~m}$ & 022 & 2673 & Descending \\
ERS & 1997.06 .25 & 1999.10 .12 & 830 days & $41 \mathrm{~m}$ & 022 & 2673 & Descending \\
JERS & 1993.09 .15 & 1996.08 .06 & 1056 days & $380 \mathrm{~m}$ & 303 & 2684 & Descending \\
\hline
\end{tabular}

The major error sources of DInSAR are atmospheric phase distortions, signal noise, inaccuracy in the orbit determination, and phase unwrapping mistakes. We consider in our case atmospheric phase distortions and signal noise the main limiting factors. The analyzed displacements have a rather small dimension (less than $2 \mathrm{~km}$ ), whereas inaccuracy in the orbit determination mainly cause relatively large-scale distortions (typically less than a couple of centimeters along the whole SAR image, i.e. $100 \mathrm{~km}$ ). Phase unwrapping was carefully performed with a region-growing algorithm (Rosen et al., 1994) and only areas with reliable information were retained. Assuming an error in the phase of one quarter of wavelength due to atmospheric phase distortions and signal noise leads to an error in line-of-sight displacement of $0.7 \mathrm{~cm}$ for the ERS SAR configuration. For JERS-1 the assumed total phase error is minor (Sandwell et al., 2008), e.g. one eighth of wavelength, leading to an error in line-of-sight displacement of $1.5 \mathrm{~cm}$.

\section{Results}

The series of ERS SAR interferograms and displacement maps of the ascending orbit shows the existence of two clear signals along the tunnel - called Cleuson and Tortin areas hereafter. As an example, the displacement map for the time period between 1995.08.30 and 1996.08.14 is presented in Fig. 2.

The valley floor upstream of the Cleuson lake is characterized by a subsidence of about $4 \mathrm{~cm}$ in the satellite line-of-sight direction. The displacement does not correspond to any geomorphological feature, rather it follows the outline of the tunnel with a width of about $1 \mathrm{~km}$. ERS SAR data of descending orbit have reduced layover to the east, as shown in the profile a-b of Fig. 3a. The similar values measured with ERS SAR data of ascending and descending orbits, with discrepancies within the estimated error of the technique, are an indication of vertical direction of displacement. The subsidence was particularly active between 1995 and 1996. Between 1997 and 1999 a small uplift of about one centimeter was instead recorded. Below the peak of Bec des Etagnes layover is preventing the retrieval of any information with ERS SAR data of both ascending and descending orbits.

A uniform movement in the slope has been as well observed above Tortin. Also in this case the displacement is restricted in time and does correspond neither to topographical limits nor to geomorphological features, even if as shown in Fig. 4 a large inactive or sub-stable deepseated landslide (moving maximally a few $\mathrm{cm}$ per year according to DInSAR data) is occurring inside the considered area (Delaloye et al., 2005). Between 1995 and 1997 a subsidence of about $4 \mathrm{~cm}$ has been measured in the satellite line-of-sight direction, as shown in the profile c-d-e of Fig. 5a. Between 1997 and 1998 a small uplift of about half a centimeter possibly occurred and after that period the displacements stopped (see Fig. 5b). In this area the displacements are not following the axes of the tunnel as in the valley floor upstream

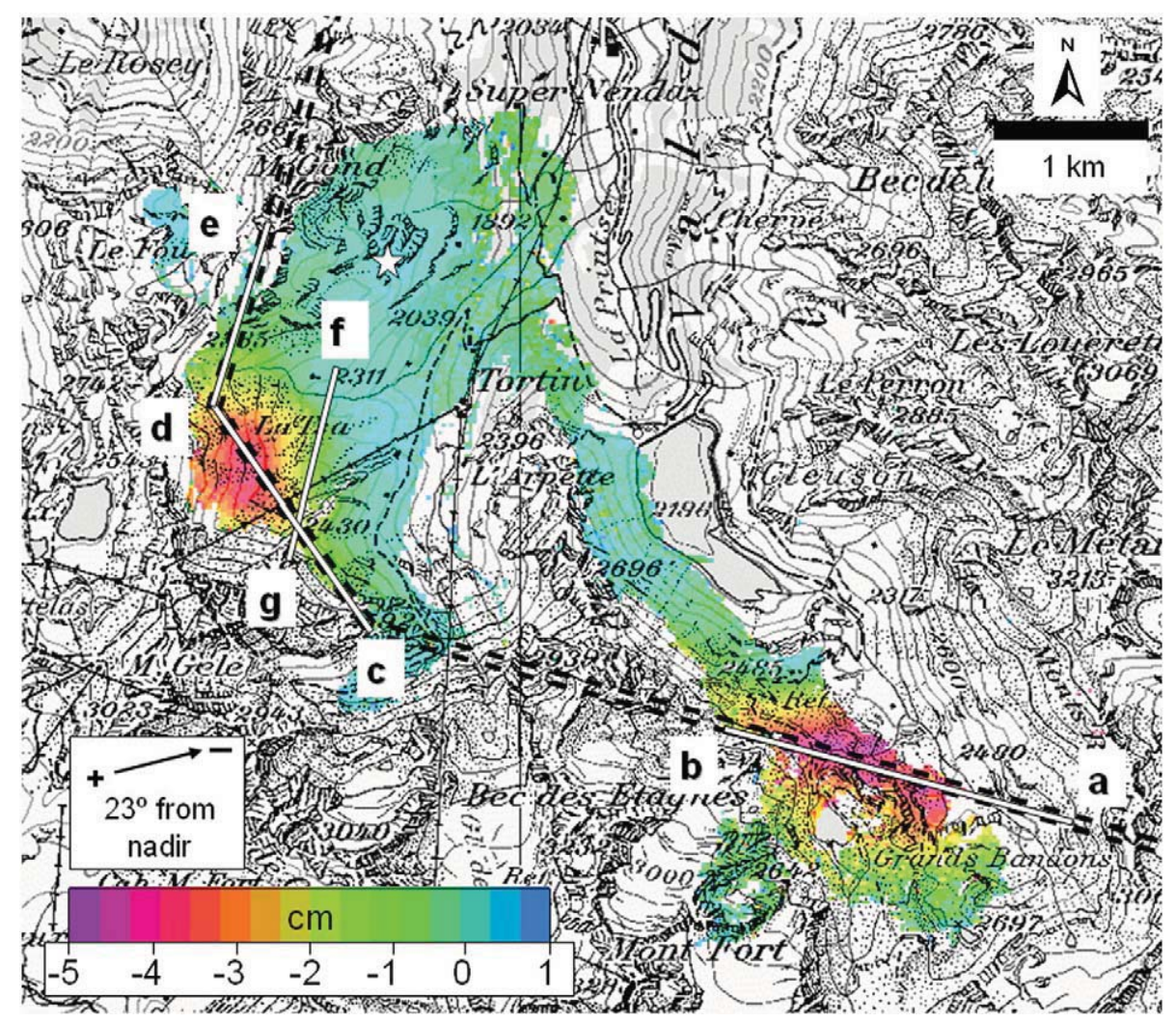

Fig. 2. Displacement map in the line-of-sight direction between 1995.08 .30 and 1996.08 .14 for ERS SAR data of ascending orbit. The star indicates the reference position of the DInSAR analysis. The tunnel is shown with a dotted line. The white lines are profiles where displacement values were extracted for different time periods. 

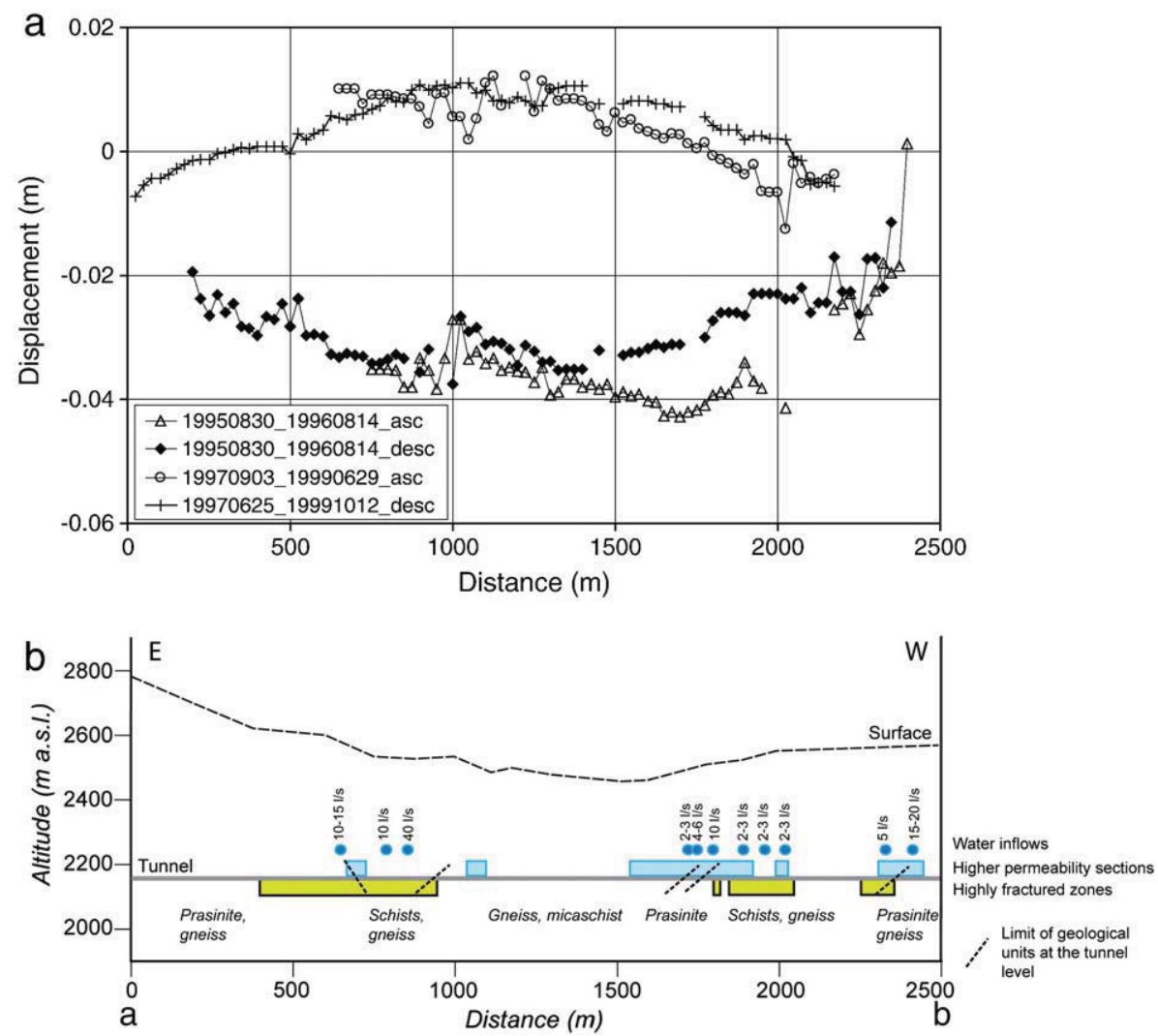

Fig. 3. a) Profiles of displacement in the line-of-sight direction extracted for different interferograms of ascending (asc) and descending orbits (desc) along profile a-b at Cleuson. b) Simplified geological and hydrogeological profile, with water inflows measured at early time after drilling (adapted from Bureau Norbert, 1998a).

of the Cleuson lake. Instead, the greatest displacement is observed at the center of a symmetric cone of depression.

We investigated the possibility of any other reason than tunnel drainage for the interferometric phase signal during the period of observation. Analysis of ERS SAR interferograms performed for the whole western Valais Alps permitted to compile an inventory of slope instabilities at regional scale (Delaloye et al., 2006), but signals similar to those observed in the valley floor upstream of the Cleuson lake and above Tortin were not detected. Fig. 5a shows that there is no significant displacement from 1993 to 1995 and for an interferometric pair with one day time interval during the summer of 1995. In addition, the strong signal related to displacement is visible in independent interferograms computed between 1995 and 1998. This excludes atmosphere, not compensated topographic phase term, and noise as possible explanations for the interferometric signal.

Moreover, a signal above Tortin was observed also in a JERS interferogram computed between 1993.09.15 and 1996.08.06 and in ERS interferograms computed from the data of the descending orbits. In ERS SAR data of the descending orbit layover is masking most of the slope under investigation apart from the lower part, where a significant displacement of about $3 \mathrm{~cm}$ in the line-of-sight direction was detected (see Fig. 6). A closer look at the results indicates that in the lower part of the slope the displacement measured with SAR data of descending orbits is larger than that measured with SAR data of ascending orbits of exactly the same time interval. This indicates that the direction of displacement in this area is not entirely vertical. Comparison of results from JERS and ERS SAR data of the descending orbits gives confirmation that there was no significant displacement between August 1993 and August 1995.

\section{Discussion}

Figs. $3 \mathrm{~b}$ and $5 \mathrm{c}$ suggest that subsidence and uplift occurred at Cleuson and Tortin in correspondence with the removal of significant groundwater quantities during the construction works of the tunnel, similar to the observations reported by Zangerl et al. (2008a, 2008b) above the Gotthard highway tunnel. We concentrate first our discussion on the signal above Tortin, where the measured surface settlement coincides spatially with a section of the tunnel passing through a geological section that induced large difficulties during the construction works and that was investigated in great detail (Bureau Norbert, 1998b; Bürgi, 1999; Maréchal, 1998; Schaeren \& Cervera, 1998).

The tunnel boring machine (TBM) was progressing from the north to the south. A sub-vertical kakirite, i.e. an unconsolidated cataclastic fault rock of about $8 \mathrm{~m}$ thickness and a very small grain size, was acting like a hydraulic seal and stopped tunneling for about three months (from 25th October 1995 to 1st February 1996). In order to lower the groundwater table level behind this seal - i.e. south of it various drainage holes were drilled through the kakirite. Water inflows of limited quantity (total discharge about $10 \mathrm{l} / \mathrm{s}$ ) but with a very high pressure (up to 14 bars) were registered in the drainage holes.

About 100 to $200 \mathrm{~m}$ behind the kakirite a borehole ("Bd9a", see Fig. 4 for location at the surface) was drilled before starting the tunneling works in order to investigate the geological and hydrogeological conditions across the so-called Cheques syncline, a pinched isoclinal syncline mainly composed of quartzite and evaporitic rocks, about $10 \mathrm{~m}$ thick, dipping about $30-50^{\circ}$ to the south-east and supposed to act like another flow barrier. The borehole was drilled to a depth of $377 \mathrm{~m}$, inclined by $60^{\circ}$, at a distance of about $35 \mathrm{~m}$ to the 


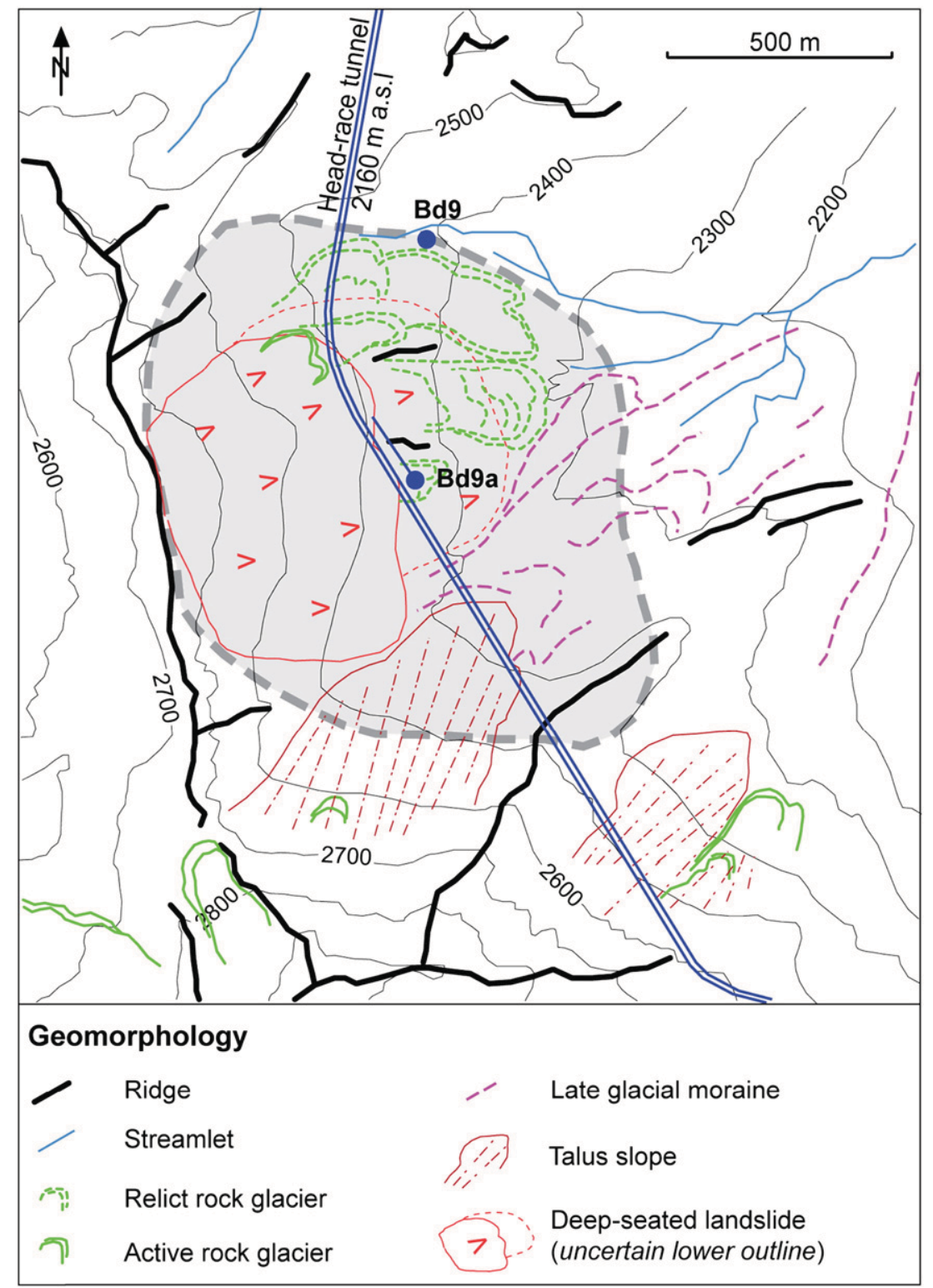

Fig. 4. Geomorphological map of the Tortin area with location of the head-race tunnel and of the piezometric boreholes Bd9 and Bd9a. The gray patch shows approximately the extent of the area affected by subsidence as detected by InSAR.

tunnel at the tunnel level, and had three pressure gauges at different depth intervals corresponding to the syncline and the geological units above and below it. At the level of the tunnel the syncline is located about $270 \mathrm{~m}$ south of the kakirite, does no more content potentially highly aquiferous evaporites (cornieules), and has an axial plane dipping about $10^{\circ}$ to the south-east. How the syncline does interact with the kakirite in the interval between the tunnel level and the surface is unknown. A second shallower borehole ("Bd9") was also drilled 300 m north of Bd9a.

In order to follow the temporal evolution of deformation a timeseries has been generated by adding the results of five interferograms of the ascending orbit from 1993.09.05 to 2000.07.19. Results for distances $1100 \mathrm{~m}, 1300 \mathrm{~m}$ and $1500 \mathrm{~m}$ along the profile c-d-e are shown in Fig. 7 and are compared to the groundwater table altitude for the two sensors of borehole Bd9a located above and below the syncline, at altitudes of 2'248 m and 2'121 m, respectively. Before the construction works the groundwater table according to pressure records at borehole Bd9a was about 300 m above the tunnel level, with a pressure level about 20-25 m less in the uppermost compartment, indicating an ascending hydraulic gradient through the syncline. From November 1995 to March 1996 the piezometric level dropped dramatically in the sub-syncline compartment by about $300 \mathrm{~m}$, i.e. essentially to the tunnel level. Two main phases can be recognized in Fig. 7: the first one, from about 2460 to $2350 \mathrm{~m}$ a.s.l., was consecutive to the preventive drainage works; the second one, from $2350 \mathrm{~m}$ a.s.l. to the tunnel level, began immediately after the TBM restarted working, penetrated and further drained the permeable, locally highly fractured rock mass (quarzitic shales) located immediately behind the kakirite. During this period two of the three sensors of the borehole actually fell dry and stopped working. Also in the compartment above the syncline the drop was large, even if less pronounced $(\sim 180 \mathrm{~m})$, and developed in two phases. The hydraulic gradient was reversed through the syncline acting thus as a semi-permeable barrier. We can therefore suppose that the sector between the kakirite and the syncline was a partially independent leaky groundwater compartment. About $300 \mathrm{~m}$ north of the kakirite the groundwater table in Bd9 dropped rapidly 

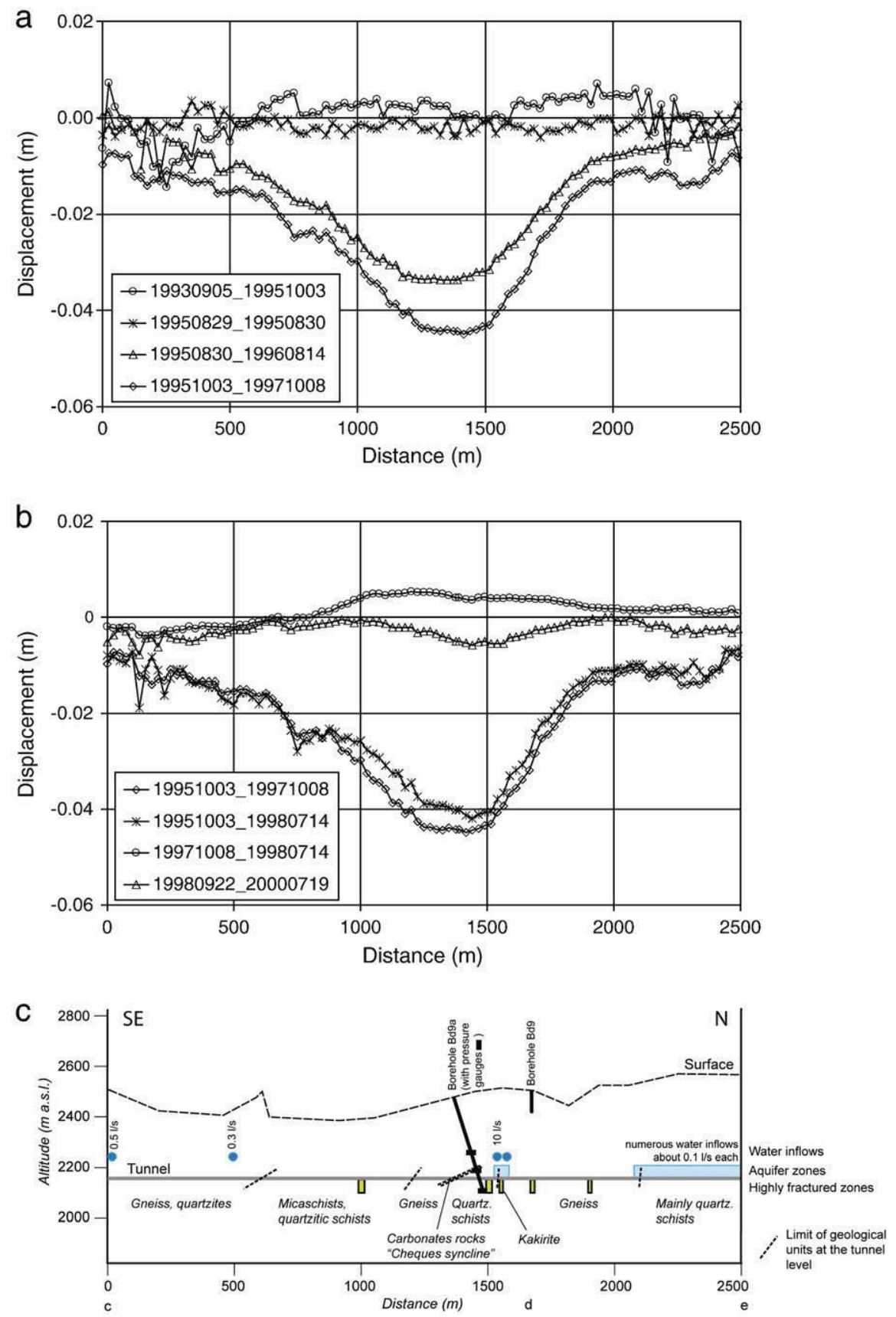

Fig. 5. a-b) Profiles of displacement in the line-of-sight direction of ERS SAR data of ascending orbit extracted for different interferograms along profile c-d-e at Tortin. c) Simplified geological and hydrogeological profile, with water inflows measured at early time after drilling (adapted from Bureau Norbert, 1998a).

from about 5 to $8 \mathrm{~m}$ depth when the TBM reached this area in early October 1995. In the following the groundwater table continued to decrease gradually until the end of 1996 until reaching 15 m depth and stabilizing in 1997. Drainage of a permeable section between the kakirite and the Cheques syncline is the main reason for the settlement cone observed at surface with DInSAR.

In Fig. 7 we can also notice that the piezometric level of the last sensor indicates a partial recovery (varying between about 80 and $230 \mathrm{~m}$ ) of the pressure after the tunnel casing (concrete segments with holes permitting some water exchange between the tunnel and the fissural aquifer) has been performed and pressurized water was flowing through the tunnel. At the same time a small reversal of the settlements (uplift) on the order of $1 \mathrm{~cm}$ has been measured with
DInSAR at ground surface. These observations indicate so far that at least part of the vertical deformations caused by the reduction of the water pressure surrounding the tunnel is elastic and reversible.

The tunnel beneath the valley floor upstream of the Cleuson lake was drilled by a second TBM between September 1995 and Mai 1996 from $\mathrm{E}$ to W. As for Tortin, both amplitude and timing of subsidence/ uplift events appear to occur in response to the drilling of the tunnel and its later casing. The involved hydro-mechanical processes are likely almost of the same type as for Tortin. Fig. 3b, however, shows that water inflows and highly fractured zones were numerous along this section, what probably explain the elongated shape of the area affected by subsidence/uplift. For Cleuson no groundwater data are available for a more detailed discussion. 


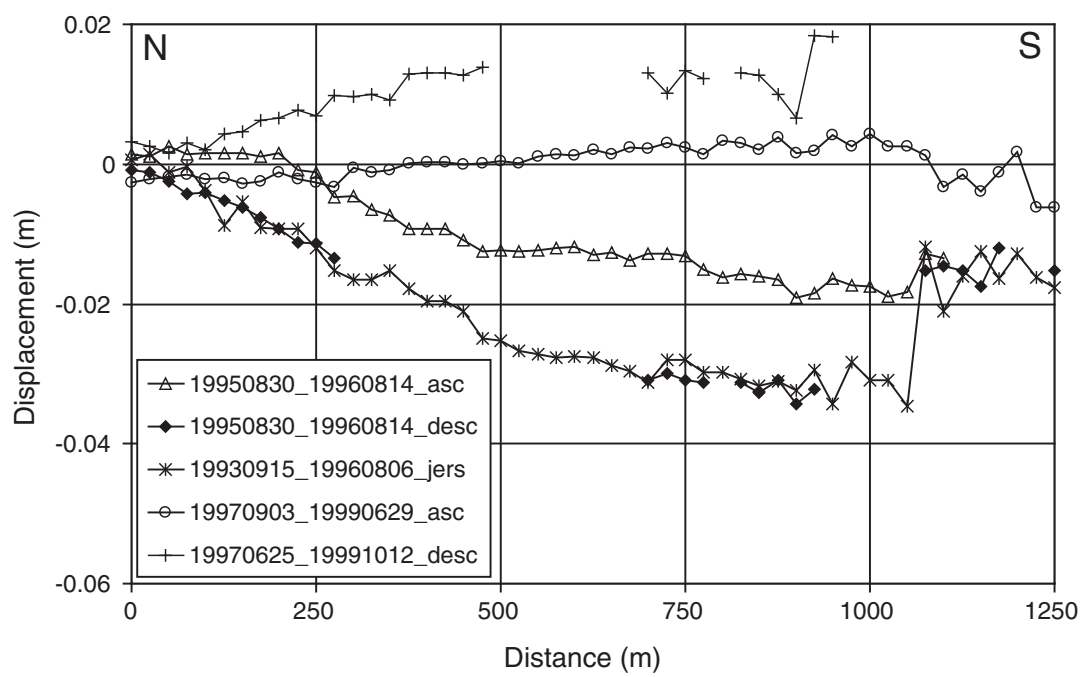

Fig. 6. Profiles of displacement in the line-of-sight direction extracted for different interferograms of ERS ascending (asc), ERS descending (desc) and JERS descending (jers) orbits along profile $\mathrm{f}-\mathrm{g}$ at Tortin.

\section{Conclusions}

In general, our data strongly support the concept that the measured surface deformations are the consequence of the closure of fractures in response to pore pressure reductions around a draining tunnel (Zangerl et al., 2008a, 2008b). Reduced pore pressure in highly conductive discontinuities can in turn lead to pore pressure drawdown within the more intact blocks adjacent to these discontinuities and the lateral propagation of rock mass deformation. As described by Zangerl et al. (2008a, 2008b) several possible hydro-mechanically coupled mechanisms might account more specifically for the observed surface deformation geometries. The measurements obtained along the Cleuson-Dixence head-race tunnel will be used in future work as input for a series of numerical models addressing in more detail the interactions between transient pore pressure changes and elastic and plastic surface deformations.

Our observations indicate that the spatial and temporal evolution of surface subsidence associated with tunnel drainage induced pore pressure changes in metamorphic rock masses can be successfully surveyed with satellite SAR interferometry in alpine regions. Surface settlements on the order of a few centimeters are important to be surveyed in alpine regions, because they are of sufficient magnitude to pose a potential threat to the integrity of any nearby large concrete structures such as thin arch dams. For both Cleuson and Tortin areas there are fortunately no concern because there are no dams located close of the head-race tunnel trajectory. However, considering that four deep rail tunnels are currently under construction through the Alps, exiting new opportunities are opened for the application of the DInSAR technology.

\section{Acknowledgments}

ERS SAR data courtesy of C1P.2338, @ ESA. JERS SAR data courtesy of J-2RI-001, (c) JAXA. DHM25 (c) 2003 swisstopo. We thank the European Space Agency and the Swiss Federal Office for the Environment for support. Energie Ouest Suisse (EOS), CleusonDixence Construction, and Bureau Norbert are acknowledged for making available the data of the tunnel construction.

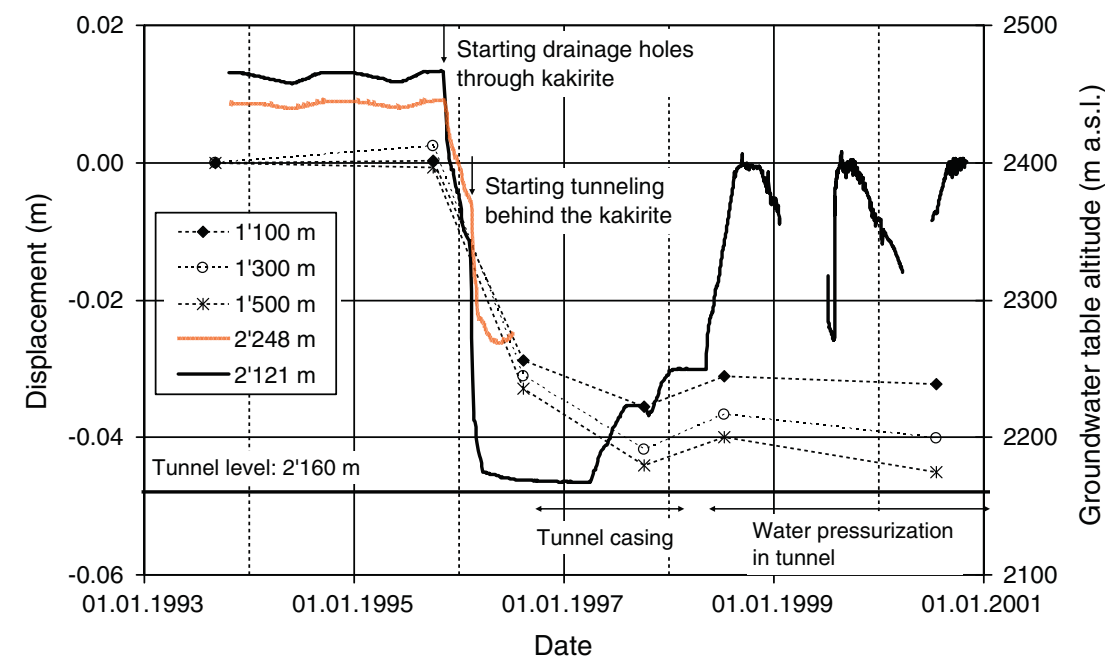

Fig. 7. Time-series of displacement in the satellite line-of-sight direction for SAR data of ascending orbit at positions 1'100 m, 1'300 m and $1^{\prime} 500 \mathrm{~m}$ along profile c-d-e and groundwater table altitude for two of three sensors of borehole Bd9a located at altitudes of 2'248 $\mathrm{m}$ and 2'121 m. For the borehole position at the surface see Fig. 4 . 


\section{References}

Bamler, R., \& Hartl, P. (1998). Synthetic aperture radar interferometry. Inverse Problems, $14, \mathrm{R} 1-\mathrm{R} 54$.

Bureau Norbert. (1998a). Aménagement Cleuson-Dixence - Géologie après exécution Rapport hydrogéologique et coupe horizontale - Lot A/B, Bureau Technique Norbert S.A. Martigny.

Bureau Norbert. (1998b). Aménagement Cleuson-Dixence - Géologie après exécution Rapport hydrogéologique et coupe horizontale - Lot C, Bureau Technique Norbert S.A. Martigny.

Bürgi, C. (1999). Cataclastic fault rocks in underground excavations: A geological characterisation. Thèse $\mathrm{N}^{\circ} 1975$, Ecole Polytechnique Fédérale de Lausanne (EPFL)

Cleuson-Dixence Construction (2009). http://www.cleuson-dixence.ch accessed 16.04.2009.

Delaloye, R., Lambiel, C., \& Lugon, R. (2005). ESA SLAM project, phase 2, Bas-Valais validation of InSAR data in permafrost zone. Final report, Federal Office for Water and Geology.

Delaloye, R., Lambiel, C., Lugon, R., Raetzo, H., \& Strozzi, T. (2006, Sept. 14-15). ERS InSAR for detecting slope movement in a periglacial mountain environment (western Valais Alps, Switzerland). Proc. 9th international symposium on High Mountain Remote Sensing Cartography (HMRSC-IX), Graz, Austria.

Kääb, A., Huggel, C., Fischer, L., Guex, S., Paul, F., Roer, I., et al. (2005). Remote sensing of glacier- and permafrost-related hazards in high mountains: An overview. Natural Hazards and Earth System Science, 5, 527-554.

Kenyi, L., \& Kaufmann, V. (2003). Estimation of rock glacier surface deformation using SAR interferometry data. IEEE Transactions on Geoscience and Remote Sensing, 41(6), 1512-1515.

Lombardi, G. (1988). Les tassements exceptionnels au barrage de Zeuzier. Publication de la Société Suisse de Mécanique des Sols et des Roches, 118, 39-47.

Löw, S., Ebneter, F., Bremen, R., Herfort, M., Lützenkirchen, V., \& Matousek, F. (2007). Annual opening and closure of Alpine valleys. Felsbau - Rock and Soil Engineering, 25, 6.

Maréchal, J. -C. (1998). Les circluations d'eau dans les massifs cristallins alpins et leurs relations avec les ouvrages souterrains. Thèse $\mathrm{N}^{\circ} 1769$, Ecole Polytechnique Fédérale de Lausanne (EPFL).

Rosen, P., Hensley, S., Joughin, I., Li, F., Madsen, S., Rodriguez, E., et al. (2000). Synthetic aperture radar interferometry. Proceedings of the IEEE, 88(3), 333-382.
Rosen, P., Werner, C., \& Hiramatsu, A. (1994, August 8-12). Two-dimensional phase unwrapping of SAR interferograms by charge connection through neutral trees. Proc. IGARSS'94, Pasadena, USA.

Rott, H., Scheuchl, B., Siegel, A., \& Grasemann, B. (1999). Monitoring very slow slope movements by means of SAR interferometry: A case study from a mass waste above a reservoir in the Ötztal Alps, Austria. Geophysical Research Letters, 26(11), 1629-1632.

Sandwell, D., Myer, D., Mellors, R., Shimada, M., Brooks, B., \& Foster, J. (2008). Accuracy and resolution of ALOS interferometry: Vector deformation maps of the father's day intrusion at Kilauea. IEEE Transactions on Geoscience and Remote Sensing, 46(11), 3524-3534.

Schaeren, G., \& Cervera, G. (1998). Aménagement Cleuson-Dixence - Rapport hydrogéologique après exécution et coupe horizontale - Lot $C$, Bureau Technique Norbert S.A., Martigny.

Schmidt, B. (1989). Consolidation settlement due to soft ground tunneling. Proc. 12th international conference on soil mechanics and foundation engineering, Rio de Janeiro, Vol. 2 (pp. 797-800). Rotterdam: Balkema.

Spreckels, V., Wegmüller, U., Strozzi, T., Musiedlak, J., \& Wichlacz, H. C. (2001, September 19-21). Detection and observation of underground coal mining-induced surface deformation with differential SAR interferometry. Joint workshop of ISPRS working groups I/2, I/5 and IV/7 "high resolution mapping from space", Hannover, Germany.

Strozzi, T., Kääb, A., \& Frauenfelder, R. (2004). Detecting and quantifying mountain permafrost creep from in situ inventory, space-borne radar interferometry and airborne digital photogrammetry. International Journal of Remote Sensing, 25(15), 2919-2931.

Strozzi, T., Wegmüller, U., Tosi, L., Bitelli, G., \& Spreckels, V. (2001). Land subsidence monitoring with differential SAR interferometry. Photogrammetric Engineering \& Remote Sensing (PEERS), 67(11), 1261-1270.

Zangerl, C., Eberhardt, E., Evans, K., \& Loew, S. (2008). Consolidation settlements above deep tunnels in fractured crystalline rock: Part 2 - Numerical analysis of the Gotthard highway tunnel case study. International Journal of Rock Mechanics and Mining Sciences, 45, 1211-1225.

Zangerl, C., Evans, K., Eberhardt, E., \& Loew, S. (2008). Consolidation settlements above deep tunnels in fractured crystalline rock: Part 1 - Investigations above the Gotthard highway tunnel. International Journal of Rock Mechanics and Mining Sciences, 45, 1195-1210. 